\title{
The relationship between athletes' perceptions of Covid-19 and communication with the psychological skills
}

\author{
Tono Sugihartono, Yahya Eko Nopiyanto* ${ }^{\circledR}$, Septian Raibowo \\ Bogy Restu Ilahi
}

Universitas Bengkulu, Indonesia

Received: 28 January 2021; Accepted 15 June 2021; Published 22 July 2021

Ed 2021; 6(2): 183-192

\begin{abstract}
Many athletes experienced psychological problems and communication with their coaches during the Covid-19 pandemic. The purposes of this study was to determine: athletes' perceptions of Covid-19, communication athletes to coaches, the psychological skills of athletes, the relationship between athletes' perceptions of Covid19 , and communication athletes-coaches with the psychological skills of Bengkulu athletes during Covid-19. The method used in this research was quantitative with a correlation approach. The population in this research was all Bengkulu athletes who would participate in National Sports Week (PON) Papua 2021, totaling 83 athletes. Sampling technique used is total sampling so that all populations were used as research samples. Research techniques and instruments used individual perception about Covid-19 questionnaire, the coaches-athletes relationship questionnaire, and the psychological skills inventory for sports questionnaire. Data analysis technique used multiple regression with SPSS at the significance level of 0.05 . The result of this study indicates that: (1) athletes' perceptions of Covid-19 have a good perception with score $70.00-84.00$, (2) communication athletes to coaches have very good communication with score $41.39-46.00$, (3) the psychological skills of athletes have a good category with score 129.20 - 159.9, (4) there was a significant relationship between athletes' perceptions of Covid-19, communication athletes-coaches with psychological skills level of Bengkulu athletes during pandemic Covid-19 with sig. score $0.005<0.05$.
\end{abstract}

Keywords: Perception; covid-19; psychological skills; athletes

do

https://doi.org/10.25299/sportarea.2021.vol6(2).6337

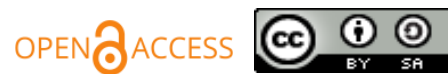

Copyright $\odot 2021$ Tono Sugihartono, Yahya Eko Nopiyanto, Septian Raibowo, Bogy Restu Ilahi

Corresponding author: Yahya Eko Nopiyanto, Department of Physical Education, Health and Recreation, Universitas Bengkulu, Bengkulu, Indonesia

Email: yahyaekonopiyanto@unib.ac.id

How to Cite: Sugihartono, T., Nopiyanto, Y. E., Raibowo, S., \& Ilahi, B. R. (2021). The relationship between athletes' perceptions of Covid-19 and communication with the psychological skills. Journal Sport Area, 6(2), 183-192. https://doi.org/10.25299/sportarea.2021.vol6(2).6337

\section{INTRODUCTION}

The Covid-19 was a national pandemic in Indonesia that has an impact on all aspects of life, including sport (World Health Organization, 2020). Many sporting events that were originally scheduled for 2020 were postponed due to Covid-19 such as Olympic \& Paralympic in Tokyo (Stambulova et al., 2020). In addition, there have also been cancellations of national sporting events such as the National Sports Week (PON) in Indonesia. Many people feel the disadvantages of postponing sports events due to Covid-19 (Schinke et al., 2020). Athletes were one of the people most disadvantaged because they have to do quarantine (Fiorilli et al., 2021). The negative impact of quarantine of athletes includes decreased psychological skills such as concentration and motivation (Belinchón-deMiguel et al., 2019). In addition, the 
existence of quarantine which requires athletes to stay at home causes major psychological problems such as increased stress, anxiety, and depression (Iancheva et al., 2020). The results of research in Italy also showed that quarantine significantly reduced the level of physical activity and that this decrease has a negative effect on psychological (Maugeri et al., 2020).

The Covid-19 pandemic has caused different perceptions for each athlete and most athletes' perceptions of Covid-19 were negative. They consider that following the quarantine during Covid -19 caused their performance to decline (Clemente-Suárez et al., 2020). The same perception between coaches and athletes of the goals achieved will have a significant impact in overcoming stress during the competition and have a significant relationship to athlete's performance (Nicolas et al., 2011). Negative perceptions about Covid-19 will lead to a less optimal training program for PON Bengkulu athletes to face the PON 2021 which will be implemented in Papua.

The Covid-19 also has an impact on communication between athletes and coaches during the Covid-19 pandemic (Ruihley \& Li, 2020). The athletes communication referred to in this research was an intensive relationship between athletes and coaches in the face of the Covid-19 pandemic. Communication in the relationship between coaches and athletes were very important factor in achieving sports goals or achievements (Nicholls et al., 2017). During the Covid-19 pandemic, athletes and coaches cannot communicate directly or face-to-face in carrying out the training programs that have been scheduled (Bijen et al., 2021).

Based on the results of previous research, it was known that out of 692 elite and semi-elite athletes in South Africa it was reported that 52\% felt depressed and 55\% felt a lack of motivation to remain active during the Covid-19 pandemic (Pillay et al., 2020). In addition, it was reported in Italy that anxiety levels also increased during quarantine and influenced the intention to engage in physical activity (Chirico et al., 2020). Based on the results of research from 252 athletes consisting of elite athletes stated that depression and anxiety were the biggest factors in psychological disorders (Vaughan et al., 2020).

Based on the results of interview with coaches, the authors believe that many factors affect the psychological skill of Bengkulu athletes during Covid-19 pandemic including, first; the perception of athletes in carrying out training programs during the Covid-19 pandemic, second; communication between athletes to coaches during the Covid-19 pandemic. Based on the author's knowledge, until now there has been no research that examines the perceptions of PON Bengkulu about Covid-19, communication between athletes to coaches during the Covid-19 pandemic, and psychological skills of PON Bengkulu athletes during the Covid-19 pandemic. So this research needs to be done as a basic effort to determine the level of preparation for Bengkulu athletes in terms of psychological aspects towards PON Papua 2021. The results of this research can be used by coaches in Bengkulu Province to develop psychological skills training programs for athletes during the Covid-19 pandemic.

\section{METHODS}

The method used in this research was descriptive quantitative research with a correlational approach. This research was conducted to determine the relationship between two or more variables, without adding or manipulating existing data (Suharsimi, 2013).

\section{Place and Time of Research}

This research was conducted in Bengkulu from August to October 2020. This study collected data by distributing questionnaires to research sample through a google form, namely athletes of Bengkulu who would participate in PON Papua 2021.

\section{Population and Research Sample}

The population in this research was all Bengkulu athletes who would compete in PON Papua consisting of 83 athletes. The sampling technique used was total sampling, so that all populations were used as research samples. 


\section{Research Variables}

The athlete's perception of covid-19 (X1) was the perspective used by athletes to conclude the Covid-19 pandemic that is happening in Bengkulu. Communication between athletes to coaches (X2) was the relationship between athletes and coaches in carrying out training programs in preparation for PON Papua 2021. The psychological skills of athletes (Y) was psychologically inherent in athletes consisting of motivation, self-confidence, anxiety control, mental preparation, team emphasize, and concentration.

\section{Data Collection Techniques and Instruments}

Data collection techniques and instruments in this research used a different questionnaire to collect data from three research variables, namely as follows:

The athlete's perception of Covid-19 collected using individual perception Covid-19 questionnaire adopted from (Clemente-Suárez et al., 2020). This instrument consists of five indicators, namely; personal concern, agreement for the delay of the national sports week, openness to experience, psychological inflexibility, and satisfaction with institutional support. Each indicator has four questions so that the total questions in this instrument were 20 questions. To test the validity of the instrument is using the Pearson Correlation and to test the reliability of the instrument is using the Cronbach Alpha. The validity of this instrument was $0.335-0.820$ while the reliability was 0.93 . This questionnaire consists of five alternative answers, namely: strongly agree, agree, unsure, disagree, strongly disagree. Each answer has a rating ranging from very positive to very negative. Based on this description, the authors compile the scoring categories as follows: (1) Every positive question that was, strongly agree $=$ score 5, agree $=$ score 4, unsure $=$ score 3 , disagree $=$ score 2 , and strongly disagree $=$ score $1 .(2)$ Every negative question that was, strongly agree $=$ score 1 , agree $=$ score 2 , unsure $=$ score 3 , disagree $=$ score 4 , and strongly disagree $=$ score 5 .

Communication of athletes to coaches collected using the coach-athlete relationship questionnaire (CART-Q) adopted from (Jowett \& Ntoumanis, 2003). This instrument consisted of three indicators, namely: closeness, mutual orientation, and complementarity. The closeness indicator consists of seven questions, the mutual orientation indicator consists of seven indicators, and the complementarity indicator there were nine questions. So the total of questions in this instrument was 23 questions. To test the validity of the instrument is using the Pearson Correlation and to test of the reliability of the instrument is using the Cronbach Alpha. The validity of this instrument was $0.463-0.721$ while the reliability was 0.92 .

The psychological skills of athletes collected using a questionnaire the psychological skills inventory for sports (PSIS) adopted from (Mahoney et al., 1987). This instrument consists of six indicators, namely: motivation, self-confidence, anxiety control, mental preparation, team emphasize, and concentration. The motivation indicator consists of eight questions, the self-confidence indicator consists of seven questions, the mental preparation indicator consists of seven questions, the team emphasize indicator consists of four questions, and concentration indicator consists of six questions. So the total of questions in this instrument was 38 questions. To test the validity of the instrument is using the Pearson Correlation and to test the reliability of the instrument is using the Cronbach Alpha. The validity of this instrument was 0.797-0.801 while the reliability was 0.795 . The statement items contained in the questionnaire, each of which has five alternative choices always, often, sometimes, very rarely, and never.

\section{The Research Procedure}

The procedure carried out by the researcher was: (1) compiling and developing research instruments, (2) compiling research designs, (3) arranging permits to research institutions and community service (LPPM) the University of Bengkulu and KONI Bengkulu, (3) giving directions to students as research data retrieval assistants, (4) collecting research data at their respective training centers of each sport, (5) classifying data based on research variables, (6) making categories of each research variable, (7) analyzing research data, (8) compiling research reports and research outcomes. 


\section{Data Analysis Techniques}

The data analysis technique used Statistical Product and Service Solution (SPPS) software version 23.0.

The steps to analyze the data were as follows:

1. Grouping data based on variables.

2. Presenting data from the variables studied.

3. Creating categorical criteria based on research variables.

Table 1. Criteria Determination Formulas

\begin{tabular}{ccc}
\hline No & Interval & Category \\
\hline 1 & $(\mathrm{Mi}+1,8 \mathrm{SD})-(\mathrm{Mi}+3 \mathrm{SD})$ & Very Good \\
2 & $(\mathrm{Mi}+0,6)-(\mathrm{Mi}+1,8 \mathrm{SD})$ & Good \\
3 & $(\mathrm{Mi}-0,6 \mathrm{SD})-(\mathrm{Mi}+0,6 \mathrm{SD})$ & Moderate \\
4 & $(\mathrm{Mi}-1,8 \mathrm{SD})-(\mathrm{Mi}-0,6 \mathrm{SD})$ & Bad \\
5 & $(\mathrm{Mi}-3 \mathrm{SD})-(\mathrm{Mi}-1,8 \mathrm{SD})$ & Very Bad \\
\hline
\end{tabular}

4. Using multiple linear regression analysis. To assess the accuracy of the regression function, the researcher used the statistical value of "r" (Sukestiyarno, 2014).

\section{RESULTS AND DISCUSSIONS}

This research examines the athletes' perceptions of Covid-19, the communication of athletes to their coaches, and the psychological skills of PON Bengkulu athletes during the Covid-19 pandemic.The results of this research based on each variable are presented in the table and graph below.

Table 2. The Athletes' Perceptions of Covid-19

\begin{tabular}{cccc}
\hline No & Category & Score & Frequency \\
\hline 1 & Very Good & $85.00-100$ & 19 \\
2 & Good & $70.00-84.00$ & 48 \\
3 & Moderate & $52.00-69.00$ & 14 \\
4 & Bad & $37.00-51.00$ & 2 \\
5 & Very Bad & $30.00-36.00$ & 0 \\
\hline
\end{tabular}

Based on table 2, it can be seen that 2 athletes have bad perception of Covid-19, 14 athletes have a moderate perception, 48 athletes have a good perception, and 19 athletes have very good perception. The result of athletes' perceptions of Covid-19 are presented in graph 1.

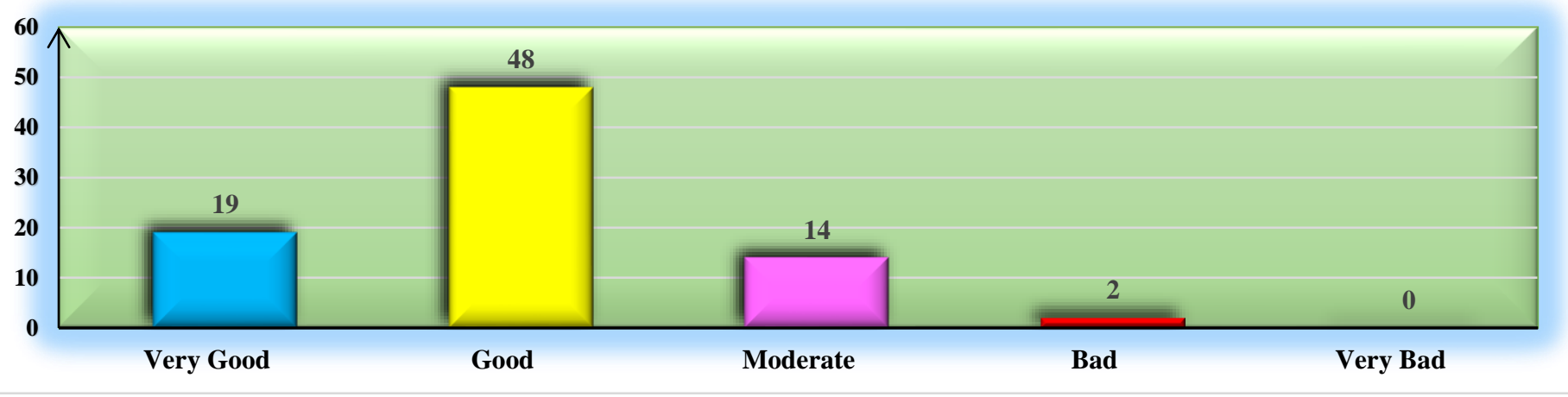

Graph 1. The Athletes' Perceptions of Covid-19

Table 3. The Communication of Athletes to Coaches

\begin{tabular}{cccc}
\hline No & Category & Score & Frequency \\
\hline 1 & Very Good & $41.39-46.00$ & 58 \\
2 & Good & $37.18-41.39$ & 9 \\
3 & Moderate & $31.82-37.18$ & 8 \\
4 \\
5 & Bad & $27.61-31.82$ & 3 \\
\\
\hline
\end{tabular}


Based on table 3, it can be seen that 5 athletes have very bad communication with their coaches during Covid-19 pandemic, 3 athletes have bad communication, 8 athletes have good communication, and 58 athletes have very good communication. The result of communication of athletes to coaches are presented in graph 2.

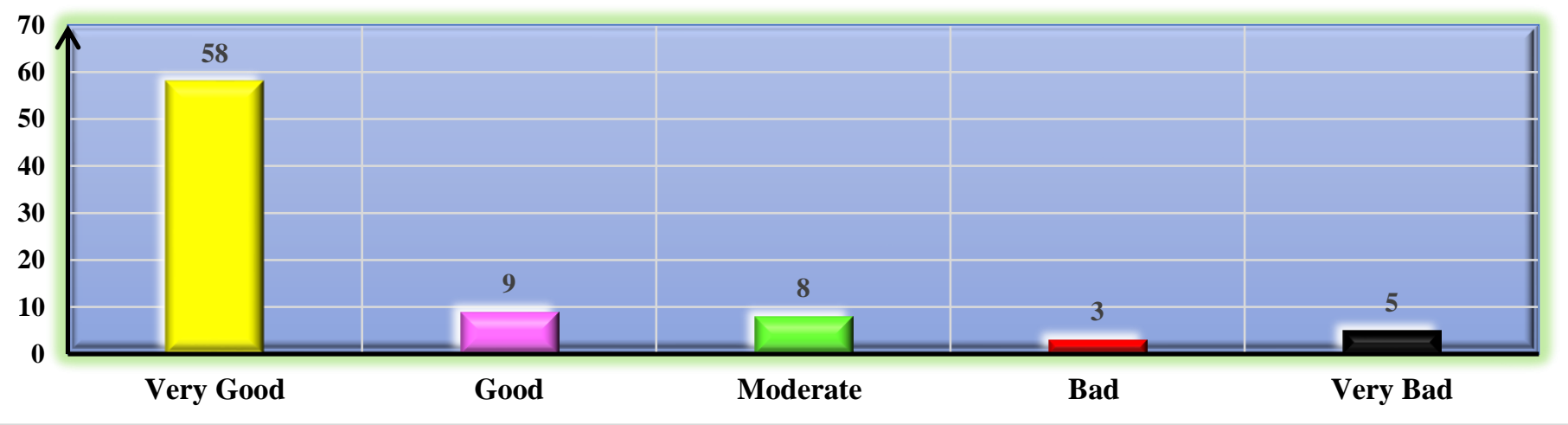

Graph 2. The Communication Athletes to Coaches

Table 4. The Psychological Skills of Athletes

\begin{tabular}{cccc}
\hline No & Category & Score & Frequency \\
\hline 1 & Very Good & $160.00-189$ & 1 \\
2 & Good & $129.20-159.9$ & 62 \\
3 & Moderate & $98.82-129.19$ & 20 \\
4 & Bad & $68.41-98.81$ & 0 \\
5 & Very Bad & $38.01-68.4$ & 0 \\
\hline
\end{tabular}

Based on table 4, it can be seen that 20 athletes have moderate category, 62 athletes have good category, and 1 athlete has very good category, and no athlete has bad or very bad category. The result of psychological skills of athletes are presented in graph 3.

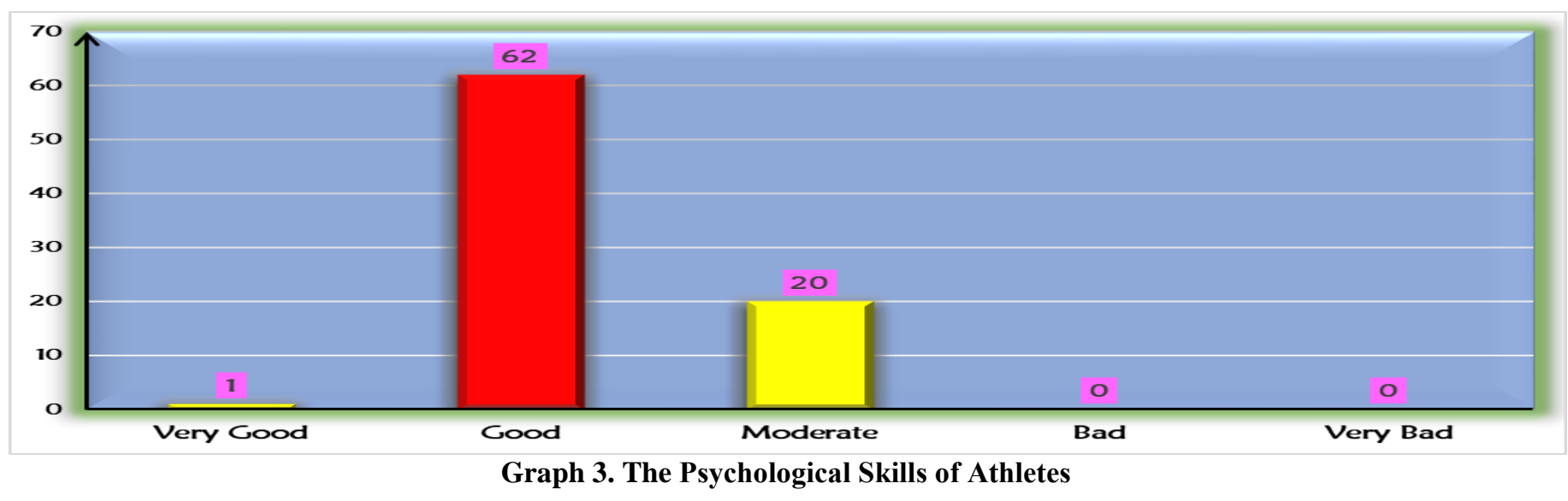

\section{Hypothesis Testing}

The researcher conducted a prerequisite test, namely the normality test and linearity test. The normality test used the Kolmogorov-Smirnov test with the following test criteria:

1. if the sig. score $<0.05$, then Ho is rejected so that the data comes from an abnormally distributed population.

2. if the sig. score $>0.05$ then Ho is accepted, so the data comes from a normally distributed population. The results of normality test data are presented in tabel 1. 


\begin{tabular}{cc}
\hline $\mathbf{N}$ & $\mathbf{8 3}$ \\
\hline Standard deviation & 0.568 \\
Kolmogorov-Smirnov Z & 1.248 \\
Asymp.Sig. (2tailed) & 0.089 \\
\hline
\end{tabular}

Based on table 5, it can be seen that the sig score in the data normality test is 0.089 . Where $0.089>0.05$. So it can be concluded that the research data is normally distributed.

Linearity test used deviation from linearity with the following test criteria:

1. if the sig. score $<0.05$, then Ho is rejected, so the data does not have a linear relationship.

2. if the sig. score $>0.05$ then Ho is accepted, so the data have a linear relationship.

The results of linearity test data are presented in table 6 .

Table 6. Results of Linearity Analysis

\begin{tabular}{cccc}
\hline Variable & Mean Square & F & Sig. \\
\hline $\mathrm{X}_{1}-\mathrm{Y}$ & 115.230 & 0.953 & 0.543 \\
$\mathrm{X}_{2}-\mathrm{Y}$ & 141.046 & 1.375 & 0.163 \\
\hline
\end{tabular}

Based on table 6 , it can be seen that the sig value $>0.05$ so it can be concluded that the research data on each of these variables have a linear relationship.

Hypothesis testing used multiple regression with the following test criteria:

1. if sig score $<0.05$ then Ho is rejected, so there is a relationship between the variables being tested.

2. if sig score $>0.05$ then Ho is accepted, so there is no a relationship between the variables being tested.

The Results of analysis multiple regression presented in table 7.

Table 7. Results of Analysis Multiple Regression

\begin{tabular}{cccccc}
\hline Model & df & Mean square & f & Sig & r square \\
\hline Regression & 2 & 619.205 & 5.575 & 0.005 \\
Residual & 80 & 111.078 & & \\
\hline Total & $\mathbf{8 2}$ & & & \\
\hline
\end{tabular}

Based on table 7, it can be seen that the sig. score 0.005 where $0.005<0.05$. So it can be concluded that there was a significant relationship between the athletes' perceptions of Covid-19, and communication of athletes to coaches with the psychological skills of athletes during Covid-19 pandemic. The level of relationship between the variables studied was 0.122 .

This research aims to determine the relationship between athletes' perceptions of Covid-19 and athletes' communication to their coaches with athletes' psychological skills during the Covid-19 pandemic. Perception is the process by which a person becomes aware of stimuli that affect one's senses (Pierce et al., 2020). Poor perceptions of current environmental conditions are a source psychophysiological that can lead to depression, mood state fluctuations, stress, and fatigue (Clemente-Suárez et al., 2020). The Covid-19 affect athlete's perceptions of the coach-athlete relationship, as recent research has found a link between stress assessment and the coach-athlete relationship (Nicholls et al., 2016). It was stated that the same perception between coaches and athletes of the goals achieved will have a significant impact in overcoming stress during the competition and have a significant relationship to athlete's performance (Nicolas et al., 2011). The athlete's perception of the coach will have a significant impact on the training process, competition, and athlete's performance (Lameiras, Martins, \& Lopes-De-Almeida, 2017).

The communication developed by athletes to their coaches is an aspect that is positively related to performance athletes. Coach-athlete communication is the relationship between the coach and athlete in carrying out training programs in preparation for PON Papua 2021. A coach will always interact with his 
athletes in training or competition. The interaction that takes place is part of the coach's effort in carrying out his duties. The coach's duties, which include technical, tactical, and strategic preparation, as well as the task of organizing, evaluating, and directing athletes, will greatly depend on the relationship between coach and athlete. When the coach and athlete are in harmony, it will have an impact on extraordinary achievements for the team. The coach-athlete relationship that is developed is not always successful or effective. The negative approach is taken when training also affects the development of the coach's relationship with the athlete. Relationship between coach-athletes was a very important factor in achieving sports goals or achievements (Nicholls et al., 2017). Poor coach communication will affect athlete's performance (Blecharz \& Wojtowicz, 2013).

Good communication between coaches and athletes can cope with stress during competition and has a significant relationship to athlete's performance (Nicolas et al., 2011). A good relationship between coach and athlete has a significant relationship to athlete's happiness (Lafreinere, 2011). The coach-athlete relationship has important implications for maximizing sports and achievement psychology between athletes and coaches (Nicholls et al., 2016). The athlete and coach relationship can be associated with sports achievement and through achievement goals (Lochbaum \& Smith, 2015). During the Covid-19 pandemic, communication built by athletes to their coaches uses long-distance or online communication. With this communication the coach can still help his athletes while training at home (Tjønndal, 2021). Communication between coaches and athletes or teamwork during the Covid-19 pandemic, which are ultimately important for team performance (Dobrijević et al., 2020). The communication built by athletes to coaches and teammates during the Covid-19 pandemic helps athletes to maintain psychological health and reduce levels of depression (Graupensperger et al., 2020). In addition to building closeness with the coach, Bengkulu athletes also communicate to build a mutual orientation and complement each other to get the maximum level of psychological skills.

The psychological skills that consist of motivation, self-confidence, anxiety control, mental preparation, the importance of the team, and concentration (Nopiyanto et al., 2021). During the Covid-19 pandemic many athletes showed a reduction in physical activity so that it had a very negative impact on psychological health (Maugeri et al., 2020). Based on the results of previous research consisting of 372 male athletes and 199 female athletes stated that: (1) depression and anxiety symptoms were lower in athletes than nonathletes, (2) there was no difference in symptoms of depression, anxiety, and stress in athletes from team sports and individual athletes (Şenış1k et al., 2020). Based on the results of research from 1132 elite athletes in Italy who had been on lockdown for one month, it was found that Covid-19 caused athlete's stress to increase (di Fronso et al., 2020).

Our research is certainly not perfect and has limitations including not discussing communication from coaches to athletes during the Covid-19 pandemic, not discussing moderating variables that strengthen or reduce the results of independent variables such as competing experience. The limitations of our research will be an interesting topic to be discussed by future researchers.

\section{CONCLUSION}

Based on the results of data analysis and discussion, it can be concluded that Bengkulu athletes have a good perception of Covid 19 and communication were built with his coach during Covid-19 pandemic was very good as well as the psychological skills of athletes during the Covid-19 pandemic was good category. This research only discusses the perception, communication, and psychological skills of athletes during the pandemic and has not connected it with other variables such as psychological training programs and achievement. Therefore, the next researcher is advised to add research variables such as the psychological training program, competing experience of athletes, and the physical activity level of PON Bengkulu athletes during Covid-19 pandemic. 


\section{REFERENCES}

Belinchón-deMiguel, P., Ruisoto-Palomera, P., \& Clemente-Suárez, V. J. (2019). Psychophysiological Stress Response of a Paralympic Athlete During an Ultra-Endurance Event. A Case Study. Journal of Medical Systems, 43(3), 1-7. https://doi.org/10.1007/s10916-019-1188-6

Bijen, F., Ferman, K., \& Ertan, T. (2021). Ten Coaching Tips for High School Athletics During Coach's Corner. Strategies: A Journal for Physical and Sport Educators, 34(0), 1-4. https://doi.org/10.1080/08924562.2021.1872009

Blecharz, J., \& Wojtowicz, A. (2013). The Athlete's Perception of Coaches' Behavior Towards Competitors with a Different Sports Level. Journal of Human Kinetics, 39(December), 231-242. https://doi.org/10.2478/hukin-2013-0086

Chirico, A., Lucidi, F., Galli, F., Giancamilli, F., Vitale, J., Borghi, S., La Torre, A., \& Codella, R. (2020). COVID-19 Outbreak and Physical Activity in the Italian Population: A Cross-Sectional Analysis of the Underlying Psychosocial Mechanisms. Frontiers in Psychology, 11(August), 1-13. https://doi.org/10.3389/fpsyg.2020.02100

Clemente-Suárez, V. J., Fuentes-García, J. P., de la Vega Marcos, R., \& Martínez Patiño, M. J. (2020). Modulators of the Personal and Professional Threat Perception of Olympic Athletes in the Actual COVID-19 Crisis. Frontiers in Psychology, 11(August), 1-7. https://doi.org/10.3389/fpsyg.2020.01985

di Fronso, S., Costa, S., Montesano, C., Di Gruttola, F., Ciofi, E. G., Morgilli, L., Robazza, C., \& Bertollo, M. (2020). The effects of COVID-19 pandemic on perceived stress and psychobiosocial states in Italian athletes. International Journal of Sport and Exercise Psychology, 1-13. https://doi.org/10.1080/1612197X.2020.1802612

Dobrijević, G., Boljanović, J. Đ., Alčaković, S., \& Lazarević, S. (2020). Perception of Cohesion in Interactive Sports Teams. Facta Universitatis, 18(2), 431-438. https://doi.org/10.22190/FUPES180831040

Fiorilli, G., Grazioli, E., Buonsenso, A., Di Martino, G., Despina, T., Calcagno, G., \& di Cagno, A. (2021). A national COVID-19 quarantine survey and its impact on the Italian sports community: Implications and recommendations. Plos one, 16(3), 1-14. https://doi.org/10.1371/journal.pone.0248345

Graupensperger, S., Benson, A. J., Kilmer, J. R., \& Evans, M. B. (2020). Social (Un)distancing: Teammate Interactions, Athletic Identity, and Mental Health of Student-Athletes During the COVID-19 Pandemic. Journal of Adolescent Health, 67(5), 662-670. https://doi.org/10.1016/j.jadohealth.2020.08.001

Iancheva, T., Rogaleva, L., García-mas, A., \& Olmedilla, A. (2020). Perfectionism, Mood States, and Coping Strategies of Sports Students From Bulgaria and Russia During the Pandemic COVID-19. Journal of Applied Sports Sciences, 1(1), 22-38. https://doi.org/10.37393/JASS.2020.01.2

Jowett., \& Ntoumanis, \&. (2003). The Greek Coach - Athlete Relationship Questionnaire (GrCART - Q): Scale Construction and Validation Paper. International Journal of Sport Psychology, 34(December 2001), 101-124. 
Lafrenière, M.-A. K., Jowett, S., Vallerand, R. J., \& Carbonneau, N. (2011). Passion for coaching and the quality of the coach-athlete relationship: the mediating role of coaching behaviours. Psychology of Sport and Exercise. 12, 144-152. https://doi.org/10.1016/j.psychsport.2010.08.002

Lameiras, J., Martins, B., Lopes-De-Almeida, P. (2017). Athletes Perception of Coaches' Leadership Style and Tendency to Cooperate Among Competitive Teams. Acción Psicológica, 14(1), 79-91. https://doi.org/http://dx.doi.org/10.5944/ap.14.1.19264

Lochbaum, M., \& Smith, C. (2015). Making the Cut and Winning a Golf Putting Championship: The Role of Approach-Avoidance Achievement Goals Elliot's Approach-Avoidance Achievement Goals. International Journal of Golf Sciences, 4, 50-66. https://doi.org/http://dx.doi.org/10.1123/ijgs.20150001

Mahoney, M. J., Gabriel, T. J., \& Perkins, T. S. (1987). Psychological Skills and Exceptional AThletic Performance. The Sport Psychologist, 1, 181-199. https://doi.org/10.1123/tsp.1.3.181

Maugeri, G., Castrogiovanni, P., Battaglia, G., Pippi, R., D’Agata, V., Palma, A., Di Rosa, M., \& Musumeci, G. (2020). The impact of physical activity on psychological health during COVID-19 pandemic in Italy. Heliyon, 6(6), e04315. https://doi.org/10.1016/j.heliyon.2020.e04315

Mirzaei, A., Nikbakhsh, R., \& Sharififar, F. (2013). The relationship between personality traits and sport performance. Pelagia Research Library European, 3(3), 439-442.

Nicholls, A. R., Earle, K., Earle, F., Madigan, D. J., Sherwin, I., \& Manley, A. J. (2017). Perceptions of the Coach - Athlete Relationship Predict the Attainment of Mastery Achievement Goals Six Months Later : A Two-Wave Longitudinal Study among F.A. Premier League Academy Soccer Players. Frontier, 8(May), 684. https://doi.org/10.3389/fpsyg.2017.00684

Nicholls, A. R., Levy, A. R., Jones, L., Meir, R., Radcliffe, J. N., \& Perry, J. L. (2016). Committed relationships and enhanced threat levels: Perceptions of coach behavior, the coach - athlete relationship, stress appraisals, and coping among athletes. International Journal of Sports Science \& Coaching, 11(1), 16-26. https://doi.org/10.1177/1747954115624825

Nicolas, M., Gaudreau, P., \& Franche, V. (2011). Perception of Coaching Behaviors, Coping, and Achievement in a Sport Competition. Journal of Sport \& Exercise Psychology, 33, 460-468. https://doi.org/10.1123/jsep.33.3.460

Nopiyanto, Y. E., Raibowo, S., \& Prabowo, G. U. (2021). Karakteristik Psikologis Atlet Pusat Pendidikan dan Latihan Pelajar (PPLP) Provinsi Bengkulu. Journal Sport Area, 6(1), 48-57. https://doi.org/10.25299/sportarea.2021.vol6(1).5572

Pierce, S., Erickson, K., \& Sarkar, M. (2020). High school student-athletes' perceptions and experiences of leadership as a life skill. Psychology of Sport \& Exercise, 51, 1-38. https://doi.org/10.1016/j.psychsport.2020.101716

Pillay, L., Janse van Rensburg, D. C. C., Jansen van Rensburg, A., Ramagole, D. A., Holtzhausen, L., Dijkstra, H. P., \& Cronje, T. (2020). Nowhere to hide: The significant impact of coronavirus disease 2019 (COVID-19) measures on elite and semi-elite South African athletes. Journal of Science and Medicine in Sport, 23(7), 670-679. https://doi.org/10.1016/j.jsams.2020.05.016 
Ruihley, B. J., \& Li, B. (2020). Sport and the coronavirus crisis special issue: An introduction. International Journal of Sport Communication, 13(3), 289-293. https://doi.org/10.1123/ijsc.2020-0254

Schinke, R., Papaioannou, A., Henriksen, K., Si, G., Zhang, L., \& Haberl, P. (2020). Sport psychology services to high performance athletes during COVID-19. International Journal of Sport and Exercise Psychology, 18(3), 269-272. https://doi.org/10.1080/1612197X.2020.1754616

Şenışık, S., Denerel, N., Köyağasığlu, O., \& Tunç, S. (2020). The effect of isolation on athletes' mental health during the COVID-19 pandemic. Physician and Sportsmedicine, 49(2), 187-193. https://doi.org/10.1080/00913847.2020.1807297

Stambulova, N. B., Schinke, R. J., Lavallee, D., \& Wylleman, P. (2020). The COVID-19 pandemic and Olympic/Paralympic athletes' developmental challenges and possibilities in times of a global crisistransition. International Journal of Sport and Exercise Psychology, 1-10. https://doi.org/10.1080/1612197X.2020.1810865

Suharsimi. (2013). Prosedur Penelitian. Jakarta: Rineka Cipta.

Sukestiyarno. (2014). Statistika Dasar. Yogyakarta: Andi Offset.

Tjønndal, A. (2021). Quarantineworkout: The Use of Digital Tools and Online Training Among Boxers and Boxing Coaches During the COVID-19 Pandemic. Front. Sports Act. Living, 2(November 2020), 1-11. https://doi.org/10.3389/fspor.2020.589483

Vaughan, R. S., Edwards, E. J., \& MacIntyre, T. E. (2020). Mental Health Measurement in a Post COVID19 World: Psychometric Properties and Invariance of the DASS-21 in Athletes and Non-athletes. Frontiers in Psychology, 11(October). https://doi.org/10.3389/fpsyg.2020.590559

World Health Organization. (2020). WHO Coronavirus (COVID-19) Dashboard. https://www.who.int/. 